This is the peer reviewed version of the following article: Laaser, $\mathrm{K}$. and Bolton, S. (2017), Ethics of care and co-worker relationships in UK banks. New Technology, Work and Employment, 32: 213-227, which has been published in final form at https://doi.org/10.1111/ntwe.12099. This article may be used for non-commercial purposes in accordance With Wiley Terms and Conditions for self-archiving. 


\title{
Ethics of care and co-worker relationships in UK banks
}

Sharon Bolton and Knut Laaser, University of Stirling

Accepted for publication in New Technology, Work and Employment published by Wiley.

\begin{abstract}
Utilising an analytical framework based on an ethics of care approach, this article examines the changing nature of co-worker relationships in UK banks under the rise of performance management practices. It illustrates that with the implementation of performance management practices in general, and electronic performance management monitoring in bank branches in particular, co-worker relationships have become increasingly objectified, resulting in disconnected and conflict-ridden forms of engagement. The analysis reveals the multi-layered and necessarily complex nature of co-worker relationships in a changing technologically driven work environment and highlights the possibilities for people to defend the capacity to care for others from the erosive tendencies of individualized processes.
\end{abstract}

Key words: co-worker relationships, ethic of care, electronic performance monitoring, bank work; disconnection; performance management; surveillance; financial services; target setting; marketisation

\section{Introduction}

Performance Management Practices (PMP) in the form of annual appraisal practices and target setting exercises is widespread since their introduction during the 1990s in public and private organisations (Bach, 2005). Against the backdrop of financialisation that encapsulates organisations' increasing dependence on financial institutions and markets, new forms of PMPs emerged that inform performance appraisals, but also impose more directly 
market driven profit expectations into the labour process (Author B; Findlay and Thompson, 2017). A new form of PMP is embodied in the widespread adaptation of Electronic Performance Management (EPM) that entails the methodical collection, storage, analysis and display of information of workers' effort via the utilization of sophisticated Information Communication Technology (ICT) (Rafnsdóttir and Gudmundsdottir, 2011:210). Focussing primarily on high skill, high wage workplaces, it is suggested that EPM systems provide mutual benefits for employees as well as employers by offering a system that supports both parties in the process of target setting, performance monitoring and evaluation (Armstrong, 2009).

However, empirical evidence overwhelmingly indicates that EMP in semi-routine workplaces is utilized all too often as a mechanism to increase managerial surveillance and control via micro-monitoring, measurement and evaluation of employees' computer, email and phone activities (Jeske and Santuzzi, 2015; Lyon, 2001; Newsome et al., 2013; Taylor, 2013). In parallel, employees and management experience EMP as a mechanism that triggers work intensification due to the interplay of the continuous monitoring of work activities and imposition of detailed performance targets on individual employees and teams as well as a reduction of job autonomy and increase in down-skilling (Carter et al., 2011; Ellis and Taylor, 2006). Linked to this observation, EPM in semi-routine workplaces has been associated with rising levels of conflict between management and employees (Author B; Carter et al., 2011; Korczynski and Ott, 2006; Taylor, 2013) and declining levels of trust and attachment of employees to the organisation and to each other (Hassard et al., 2009; Jeske and Santuzzi, 2015; McCabe, 2015). Yet, despite the spread of EPM systems in semi-routine workplaces and the observation that under EPM social relations are negatively impacted (Fevre et al., 2012; Hodson, 2008), there is scant attention paid to the impact EPM has on coworker relationships (CWR) in different contexts. 
This article seeks to address the gap in the literature and also responds to recent calls to explore more systematically the dimensions of horizontal caring relationships in organisations (Gabriel, 2008; Sayer, 2007). Qualitative interviews with branch workers and branch managers from UK banks are situated within an analytical framework based on an ethics of care (EOC) approach. EOC successfully combines a political economy approach with a focus on caring relationships (Tronto, 1994), depicting how caring connections develop or decline between people depending on available resources (both material and immaterial). The approach is especially interested in examining the extension of market principles, that introduce values of rationality and instrumentality, into previously non-market dominated fields (Held, 2005). This article suggests that EOC captures the challenges and possibilities for employees to defend the capacity to care for co-workers from the competitive as well as individualised performance norms and sophisticated surveillance systems that an EPM workplace regime represent. In this way, EOC is utilized as a framework to render visible both the munificent and penurious nature of social relationships in an industry that has been known for fostering dysfunctional behaviour (Froud et al., 2017) and dehumanizing workplace regimes (McCabe, 2015).

\section{Context}

Banking industries across the globe are a particularly interesting empirical field for explorations of the changing nature of work, employment and its social relations. Research illustrates that for the majority of the post-Second World War era, employment conditions in banks were relatively privileged in the context of a tightly regulated and modestly competitive financial market (Booth, 2004). Banks offered life time employment, a robust internal labour market with stable career ladders and relationships between employees and managers that were shaped by a unitary ideology that was embedded in a managerial 
paternalism (Author A; Knights and McCabe, 2001). Work in bank branches was dominated by clerical work due to the absence of information computer technology (ICT) until the early 1980s (Crompton and Jones, 1984; O’Reilly, 1992). When ICT was subsequently introduced, manual administrative tasks were substituted by customer interaction and the management of financial transactions and customer accounts via computer terminals (Halford and Savage, 1995). It has been argued that bank staff, at first, enjoyed greater levels of autonomy and skill variety as mundane tasks were reduced and the emphasis on customer interaction granted greater discretion (Booth, 2004). Employment conditions, the nature of work and its social relations in the banking industry underwent a radical change under Thatcherite legislation that deregulated the financial markets in the late 1980s, creating heightened competition between the previously non-competing building societies, clearing banks, insurance corporations and foreign banks (Froud et al., 2017; Hodgson, 2003; Regini et al., 1999). In this environment clearing banks searched for ways to improve their position in the market, resulting in waves of large-scale redundancies and investment in telephone and internet banking; thus enabling the outsourcing of back office work to administration centres in the UK and overseas (Knights, 1997). Sales became a greater part of bank work in the 1990s; increasingly driven by explicit sales targets, performance related pay, and disciplinary policies for underperformance (Author B; Storey, 1995).

Some argue that the dominant sales culture is driven by an exclusive focus on delivering shareholder return, creating a 'structured irresponsibility' (Honneger et al., 2010) in which 'dysfunctional behaviour' such as mis-selling and the marketing of incompatible products to customers is fostered (Froud et al., 2017). The further prioritization of sales over customer service is illustrated by the introduction of EPM during the 2000s (Author B; Ellis and Taylor, 2010; Hodgson, 2003). Here, it is suggested that EPM is encoded in the utilization of computerised technology and sophisticated software that enables management 
to micro-monitor worker effort and translate it into performance rankings that are communicated to employees on a monthly or weekly basis, whilst also informing bonus pay or disciplinary actions (McCabe, 2015; Taylor, 2013).

It is suggested that the introduction of EPM is welcomed by employees when it replaces ambiguous evaluation techniques and reward practices with accountable and valid management systems (Rafnsdóttir and Gudmundsdottir, 2011). However, workplace research indicates that EPM in the banking industry fosters an intensification and degradation of the labour process, leading to employees feeling increasingly objectified and dehumanized by the centralized designed and top-down EPM regime, which triggers conflict-ridden relationships amongst branch workers and branch-workers and managers (Hassard et al., 2009; Fevre et al., 2012; McCabe, 2015). Paradoxically, though the banking industry attracts increasing attention from critical scholarship, evidence of the impact of EPM on horizontal co-worker relationships remains scarce. This article aims to contribute to this literature by exploring the different shapes and forms of mutual care between co-workers, against the backdrop of an EPM driven labour process in the UK banking industry.

\section{Co-worker relationships}

It appears that research on co-worker relationships holds a 'secondary place' in the sociology of work (Hodson, 2008). A significant reason for this is the overarching focus on management-worker relationships, but also a popular view that, thanks to the increasing marketisation of work and employment, employees are unable to connect to one another and develop shared understandings and sentiments that spill over the instrumental frame of the employment relationship. Prominent examples of such a position are the writings of Catherine Casey (1995) and Richard Sennett (2006). For Sennett, the heightening of short-term economic imperatives that shape employment practices in organisations produce highly calculative and 
superficial ties between co-workers, creating diminishing opportunities to find meaning at work and develop as social and moral beings. Taking the idea a theoretical step further, Casey argues that people's agentive capacities are undermined by an organisation's attempt to carefully manufacture employees' identities. Employees are understood to internalize the manufactured values; reducing the ambiguities that are triggered by instrumentalisation and gaining 'psychic comfort' (Casey, 1995:134; McCabe, 2015). Such accounts are useful for providing a critical analysis of the rise of corporate culture programs and the pressures they represent for people to behave and act according to the interests of the organisation. Nevertheless, a counter argument suggests that within this framework employees are conceptualised as docile subjects who are unable to experience care and concern that is not engineered by the organisation (Sayer, 2007). There is an exaggeration of the extent to which organisations control social relationships; thus providing little insight into how people continue to express care and commitment that goes against organisational value textures.

In contrast, a range of literature reveals how co-worker relationships make a difference between experiencing work as meaningful and dignified, or as degrading and as a source of suffering (Hodson, 2001; Rumens, 2010; Sloan, 2012). Indeed, horizontal relationships in organisations may embody various types of practices and relationships, ranging from emotional support to the exchange of private information, but also mistreatment and hostile practices such as bullying (Fevre et al., 2012; Hodson, 2008; McGuire, 2007). Research analysing social relations at work from a sociology of work perspective emphasise the organisation of work and the way technology enables or constrains the sharing of experiences between co-workers via discretion, occupational control and team-work (Edwards and Raminzez, 2016; Fevre, 2003; Hodson, 2008; Lopez, 2010). For example, much of this literature suggests that camaraderie in and beyond working teams emerges under employment conditions that enable team-work, responsible autonomy and employee voice mechanisms, enhancing co-workers' ability to 
support and defend each other from management practices. Classic workplace ethnographies provide rich insights into the dialectical relationship between the particularities of workplace regimes and co-worker relationships. Hall's ‘American Working Men’ (1984), Burawoy’s, 'Manufacturing Consent' (1978) and Roy's 'Banana Time' (1954) are revealing in the way they explore informal horizontal relationships under the Fordist mass production regime that rested on numerical control technology and how they shape and re-shape the material reality of work. The vivid portrayals of active human agency are particularly represented in decisions to reduce work effort or not declaring work done; hence accepting a restriction of bonus payments in order to maintain informal work effort norms. These celebrated works illustrate that people's creative actions, such as fiddling the system, allow them to humanise work and escape its drudgery even when remaining tightly bound by the labour process and where activities may be understood not as conflict or resistance but self-manufactured consent (Burawoy, 1985; Roy, 1954). Employees create a bottom-up culture that rests on shared experiences and identities that enable them to form spaces of autonomy in the face of managerial and technological control (Ackroyd and Thompson, 1999: 54). Such studies conceptualise employees as wilful and creative actors whose actions are driven by collective, as well as individual, interests that reflect attempts to create and defend spaces of autonomy at work; experiencing recognition for their efforts from co-workers and management in the context of the structured antagonism of the employment relationship (Boreham et al., 2008). Arguably, a significant, but mainly unacknowledged, feature of social relations between coworkers described in these studies is the way they rest not only on concrete interests, but also on moral sentiments. These sentiments are encoded in shared ideas of fairness, decency and well-being; informing caring relations between employees (Fevre, 2003; Sayer, 2007; Zelizer, 2010). 
More recent studies from Pearson et al. (2001) and Fevre et al. (2012) offer similar insights as they illustrate that co-worker relationships are guided by respect, recognition, care and attention to others' well-being, suggesting that over time commitments overlap and result in shared sentiments and interests. However, as these accounts place co-worker relationships within the structured asymmetry between capital and labour, they can also be corrupted by the particularities of workplace regimes and the type of relationships and behaviours they are prioritizing. Indeed, a strong link is promoted between the individual and organisational strategies via employer managed corporate collectivity (Bach, 2005); which is particularly inherent in performance management practices that tie the individual to organisational goals (Taylor, 2013).

There is increasing evidence which suggests that the individualisation and instrumentality that EPM fosters via demanding performance targets, harsh disciplinary policies and on-going monitoring and evaluation of work effort in general and computer, email and phone activities in particular, undermine citizenship within organisations, whilst heightening levels of mistrust and infighting (Author B; Grosen, 2014; Hodson, 2008; Roscigno et al., 2009; Sloan, 2012). The rise of incivility amongst employees has been found to be particularly prevalent in the financial industry that witnessed a radical transformation from paternalistic to market-driven management in the context of the deregulation of financial markets (Author B; Knights, 1997; McCabe, 2014). Korczynski and Ott's (2005) rich ethnography in Australian banks, and McCabe's in-depth case studies of UK banks (2014; 2015) illustrate the prevalence of antagonistic relationships between co-workers in the context of high levels of job insecurity and the implementation of commission based pay and individualised work effort targets that were monitored and evaluated by ICT. Against this backdrop, Korczynski and Ott argue that fierce competition for customers and bonuses led to 
instrumental and hostile relationships between co-workers who related to each other primarily via the logic of the 'cash nexus'.

Yet, what factors might determine caring and/ or instrumental co-worker relationships continue to be subject to debate (Hodson, 2008). For example, Hodson (2008) suggests that the type of managerial control (direct vs. bureaucratic control), the size of the workplace (large vs. small), the organisation of work (teamwork vs. individual work) and forms of training (peertraining versus formal training), amongst other factors, determine whether CWR will foster solidarity (direct control, large workplace, teamwork and peer-training as contributing factors) or feature competitiveness and in-fighting (bureaucratic control, small workplaces, individual work and formal training as influential factors). However, evidence from recent service work research highlights that even in smaller workplaces that are characterized by bureaucratic and technological control systems and minimal formal peer-training, supportive co-worker relationships remain crucial for employees, serving to create social spaces for emotional release, mutual recognition and respect and buffering negative experiences at work (Author B; Korczynski, 2003; Taylor and Moore, 2015). Thus, research on how CWRs may develop and change over time is needed to represent the complexity of social relations under changing workplace regimes. The analysis presented here, drawing on rich data and framed by an ethics of care approach, offers insights into how caring connections develop differently across two different groups of bank workers with different experiences of work and its social relationships.

\section{An ethics of care approach to work and employment studies}

Ethics of care is an approach rooted in relationality and humanity's reliance on caring relationships - whether these relationships are with other individuals, family, institutions, or the state (Fineman, 2004; Held, 2006). The strength of the underpinning relational ontology is that it illuminates the importance of caring relations as being relevant not only to the private 
realm of friends and family but to politics, the organisation of markets and social life (Donati and Archer, 2015:18; Held, 2006; Tronto, 2006). Hence relationality is only ever conceptualised in social, political and economic context so that there is an understanding of the pressure points in society that may undermine people's capacities to care for one another and the communities in which they live and work. The notion of human flourishing is firmly placed within institutionalised structures that may enable or constrain the capacity to flourish in every sense; as individuals and communities (Sayer, 2011). Though bearing many similarities with virtue ethics, in that caring is proposed as the primary virtue and neither approach relies on abstract rules to guide action, care ethics emphasises caring relations and the practice of care rather than focusing on the character of individuals. Ethics of care investigates the gender of care-givers and/ or their status in society and/ or the resources they have available to support caring activity. It does not consider people as good or evil in and of themselves but looks at how groups and individuals are connected to each other and to society. It is the relational aspects of caring action that are important (Sayer, 2011; Held, 2006) and those that offer and receive care are valued (Gilligan, 1982; Held, 2006; Kittay, 1999; Kittay and Feder, 2002; Tronto, 1993). This suggests that people care about others because of overlapping commitments; including 'the cooperative well-being of those in the relation and the well-being of the relation itself' (Held, 2006:12). Ethics of care focuses on the processes and labour involved in caring relations and both the objective and subjective results (Kittay, 1999). Hence why it lends itself to being used as a means of revealing how there are layers of relationality, that can be understood as connected and that shift and change in line with the resources made available to different groups within a market society (Held, 2006; Nodding, 1984; Sevenhuijsen, 1998; Tronto and Feder, 2002).

Ethics of care is presented here as an analytical framework that offers the means to understand individual vulnerability and dependency whilst revealing the connecting tissue that 
binds people to communities and institutions that are firmly situated within market and state dynamics. Critique is focused on the way thinking about human development has become conceptually crippled by the political rhetoric of the individual subject (Benhabib, 1992; Held, 2006; Gilligan, 1982; Robinson, 2011; Sevenhuijsen, 1998; Fineman, 2004), in what has been described as an 'autonomy myth' (Fineman, 2004). This individuality is understood in the narrowest sense, as being responsible for oneself and direct dependents. It is also focused on economic responsibility. Therein, dependency emerges as a universal and inevitable part of the human condition (Kittay, 1999; Sayer, 2011). Within an ethics of care framework dependency is understood as complex and multi-faceted, taking many different forms and developing differently over time - psychological, physical, emotional, economic - so that it is understood that people are embedded in 'relationships of dependency' (Kittay, 1999). Focusing on dependency under-mines the notion of the autonomous, rational, utility-seeking individual and displays people as reliant, reflective, reciprocal agents who require material support in order that they may flourish. Such support will be delivered via caring relationships that feed into a broader system of just distribution of opportunities and rewards (Held, 2006; Nodding, 1984; Sevenhuijsen, 1998; Tronto and Feder, 2002). As Held states: 'the view of persons as embedded and encumbered seems fundamental' (Held, 2006:15).

Ethics of care offers a normative statement in that it examines relationships and emphasises the significance of caring for a just society. It reveals the failures of a model of economic rationality for life in and out of the private realm, highlighting if and how people resist commodification and thereby instrumentalization of themselves and their social relations. For our analysis it offers the connective analytical tissue to show how people are connected to each other, to the state and to the market (as both producer and consumer). That is not to say all relationships are positive, as ethics of care acknowledges, interpersonal relations embody a combination of instrumental and caring motives; hence as a framework it offers a capacity to 
evaluate situations differently, opening human relations and the particularities of the structure in which they are embedded up to scrutiny rather than assume they can be prescribed or proscribed. Thus there are no universal judgements on what is the right thing to do and there is also potential for conflict in moral evaluations (Gabriel, 2008; Sayer, 2011). Framing vivid qualitative data, an ethics of care approach places co-worker relationships within economic, political and social contexts; thus revealing the full spectrum of human relations.

\section{Research context and methods}

The article draws on data which aims to capture branch workers' and branch managers' lived experiences of the radically changing workplace regime in UK banks over the last three decades. The empirical material consists of qualitative in-depth interviews and documentary evidence. Thirty-nine in-depth interviews were conducted between 2011 and 2014 with bank workers and managers, lasting between one and three hours and culminating in 82 hours of interview material. In addition, company documentation from all five banks is used as a complementary data source. Company documents ranged from performance management guidelines to performance reports and rating scales. The method of interviewee sampling was purposeful (bank workers and managers had to possess at least ten years of work experience and be employed in one of UK's leading retail/clearing banks) and relied on self-selection and snowball sampling after a research description and invitation had been sent through relevant professional networks.

The thirty-nine participants are, or have been, employed in one of the five biggest clearing and retail banks in the UK. Thirty-four participants are employed in a range of nonmanagerial positions, whilst five hold a managerial position in a bank. There are three distinct groups of bank employees and managers: seventeen interviewees entered the banking industry 
in the late 1970s/ early 1980s; eleven individuals began employment in the banking industry between the mid-1980s/ early nineties, and eleven individuals worked for a bank from the midnineties and early 2000s onward. All five banks are leading national banks in the UK who dominated the financial market for large parts of the $20^{\text {th }}$ century and continue to belong to the group of the most profitable clearing banks after the liberalisation of the financial industry and the financial crisis. Interviewees are almost equally spread across the five banks; nine interviewees at banks 1-3 respectively, seven interviewees at the fourth clearing bank and four interviewees at the fifth bank. The gender proportion of the overall sample is balanced, representing twenty female interviewees and nineteen male interviewees. Despite differences in corporate strategies, market share, total number of employees and branches between the leading national banks (Watson, 2004), previous research suggests that the banking industry is and has been traditionally homogenous when it comes to the organisation of work and management practices in branches (Gall, 2008). All interviews were, with consent, digitally recorded and transcribed. Interviewees were aware of the aims and objectives of the research project and agreed to talk about the subject. To guarantee anonymity, biographical and organisational details and names of all interviewees have been changed.

Interviews with bank workers and managers were semi-structured and open-ended, enabling interviewees to elaborate on experiences and situations they perceived to be important. Influenced by a 'work history approach' (Dex, 1991), interviewees were asked to reflect on changes in the nature of work, employment conditions in banks, and if and how horizontal and vertical social relationships in the branch changed. The analysis of the empirical material rests on several cycles of analysis that included thematic manual coding and a categorisation of themes in 'first-order' and 'higher-order' codes, using NVIVO, a qualitative data analysis program. Thematic analysis was conducted to identify recurring themes in the narratives. This process enabled an understanding of the multi-layered and complex narratives 
that provide insights into various contexts that foster different inclinations for branch employees to care (or not) for each other. These narratives, in combination with documentary evidence, are drawn together into a coherent analysis that illuminates the different but yet complementary experiences of interviewees, beginning with an exploration of the nature of bank work under performance management practices, moving to the analysis of different forms of caring co-worker relationships that entail dependency, instrumental relations and attempts to humanise disconnected relations.

\section{Bank work under performance management and the decline of an Ethics of care}

Interviewees from all banks are subject to a range of quantitative and qualitative performance targets that they are given by the branch manager on an annual and, in some cases, bi-annual basis. Quantitative performance targets embody concrete and individual work productivity norms that are time and task bound, relating, directly and indirectly, to the selling of financial products to customers.

"The most important targets are sales targets. For example, I have to sell x-number of insurance products, $x$-number of mortgages and need to get a certain number of new customers in to open a bank account" (Bob, Customer Advisor, Bank B, employed since 1996).

Alongside quantitative targets, banks have introduced qualitative targets in the form of behavioural descriptors. The number of behavioural descriptors varies between twelve in Bank A to twenty-eight in Bank D and include, but go beyond, the following examples drawn from the banks' HR documentation: 'Employee supports others and helps them achieve their goals' (Bank A); 'Employee celebrates and recognises excellent achievement of others' (Bank C); 'Employee does not prioritise his/her own agenda', 'Employee acts according to what is right for the organisation, community and customer' (Bank B). 
Empirical material suggests that the combination of quantitative and qualitative targets serve two main purposes. First, as a reaction to the widespread criticism banks faced in the post-financial crisis era for the mis-selling and inappropriate marketing of products (Froud et al., 2017), the implementation of 'caring' norms, such as compassion, attachment and support via qualitative targets, act as an attempt to safeguard and counteract the failures of the marketized (and mythical) notion of a rational, utility seeking individual (Fineman, 2004) that quantitative targets promote. Yet, the majority of interviewees suggest that quantitative targets in the form of sales targets remain crucial for performance evaluations in the post-financial crisis environment, whilst qualitative targets play a secondary role. Indeed, sarcasm is inherent in many narratives when they reflect on the change made in labour process in banks in the postfinancial crisis environment that pinpoint towards an intensification and further escalation of performance targets.

"The bank wants us to sell products- full stop. When we also meet behavioural targets, we get a 'well done' and pat on the shoulder, but they don't matter. It is all about selling and as long as no one complains about you, especially customers, you are good to go" (Alice, Mortgage Advisor, Bank A, employed since 1988).

“The key difference between pre-financial crisis bank work and post financial crisis bank work is that performance targets are higher and the introduction of qualitative targets made work even more demanding. It takes its toll on people and how they treat each other" (Martha, Customer Advisor, Bank D, employed since 2005).

Second, interviewees insightfully suggest that qualitative targets are implemented to enhance the power of management. Thanks to the vague and highly subjective character of the majority of behavioural descriptors, employees have difficulty in challenging targets (Taylor, 
2013). Indeed, as Kyle's narrative indicates, qualitative targets are seen to open the door for line-management to question performance without the need to present evidence.

Qualitative targets count towards the ranking, but if your sales numbers are great, no one cares about how tidy your desk is. Qualitative targets come into play only when the manager looks for ways to rank employees down, or when your sales performance is not satisfactory. Then, qualitative targets make it easy for management to push you out by downgrading you even further. Qualitative targets are, like we call them, a wild card (Peter, Senior Teller, Bank D, employed since 1985).

Bank worker performance is fed into a personalized balance scorecard (BSC) which represents the heart of the EPM system in banks. The electronic monitoring system is wide ranging, including the recording of bank workers' login and logoff times on computers, the number and length of each customer interaction, and incoming and outgoing phone calls. However, it is the BSC that is central to the labour process. The selling of financial products is recorded automatically by the electronic system thanks to the standardised computer programs bank workers have to use when meeting customers, and qualitative targets are assessed and fed into the system by management. In that way, the BSC operates as a live electronic monitoring and evaluation tool which provides bank workers, as well as managers, with a wealth of daily updated details on, for example, the products they have sold, customers they have met, and behavioural criteria they have been assessed against. The BSC is appreciated by some bank workers because of the way it provides clarity over the assessment of their performance, however it is also suggested that the constant monitoring, measurement and calculation of their work fosters an instrumental and objectified approach to their role and the relationships they engage in; thus undermining the development of dispositions of care. 
"Everything we do feeds into the scorecard that gives us points for performance and results in a total score (...) The stats and figures tell me what I need to focus on. I am checking it almost every day" (Mick, Senior Customer Relationship Advisor, Bank A, employed since 1984).

"The balance scorecard is central to what we do here. Compared to previous systems, it is very straight forward and transparent. Yet, I noticed how it changes the way we work. Everybody is concerned now to get the score that secures their job, or a score that makes them eligible for a bonus. Everything that is not assessed and recorded in the scorecard becomes irrelevant" (Paula, Mortgage Advisor, Bank D, employed since 1999).

The design of the EPM system in banks fosters an individualised and instrumental approach to work, and competitiveness and conditionality are amplified. Bank workers illustrate that in all banks included in the research sample a forced distribution curve is applied by management when evaluating individual scorecard statistics, resulting in a categorization of employees' actual performance into statistically pre-determined categories of 'over', 'satisfactory', and 'under' performers. Though the concrete statistical distribution differs between the banks, the market conditionality and deeply competitive logic of the evaluation of performance according to forced distribution curves is the same: Irrespective of whether branch staff meet or over exceeded their targets, a certain percentage of staff will be categorized as underperformers. This is all the more salient as performance categorizations are connected to individualised disciplinary and reward practices. Disciplinary practices entail informal and formal performance warnings by management, but also feature forced exits of bank workers who repeatedly have been categorized as underperformers. Rewards include modest bonus payments or giveaways for employees who have been categorized as over performers. 
The combination of the EPM and the BSC foster an objectification of work and its relationships and creates an environment that renders people individually vulnerable. In this environment, opportunities for employees to develop overlapping identities that are essential for an understanding of others as interdependent and vulnerable beings is undermined (Sayer, 2007; Sezlier, 2010). Indeed, the competitive and individualist nature of the EPM driven labour process fosters dispositions of self-interest and opportunisms, promoting employees as dependent first and foremost on themselves, paving the way for an instrumentalisation of social relationships at work (Kittay and Feder, 2003 Zelizer, 2010). This is evident in the way conflict between bank workers and managers over performance rankings becomes a ubiquitous feature of work. At the heart of social relations under EPM is the individualization that is often accepted by bank workers, and the antagonistic co-worker relationships that feature fierce competition, and occasionally incivility, that renders a colleague as a threat to one's own ambitions and livelihood. This is illustrated in Margret's narrative, which portrays a steady hum of disconnection at work between employees, pointing towards the dominance of relationships that are characterised by competition and distrust.

"Many think along the lines of "what can I do to make me look better than the person next to me'. It's competition for performance rankings". (Margret, customer service manager, Bank D, employed since 1991)

For the majority of bank workers who are recruited under the performance driven employment relationship, the experience of a marketized system that heightens values of competition and self-reliance is not in conflict with previous employment experiences and perceptions of how they should relate towards one another. They often perceive it as 'the way it is', and bank workers rarely contest or negotiate the new social order and its consequences for social relations at work. As Ciara describes, recently recruited bank workers tend to comply 
with the competitive and instrumental texture of qualitative and quantitative performance targets, and electronic performance monitoring.

"Most branch workers nowadays are recruited straight from school or have worked in retail occupations before making the move to the branch. Branch workers are treated like numbers by management and especially younger staff behave accordingly (...) They have low levels of attachment to the job and to co-workers, they come and go'. (Ciara, Branch Manager, Bank B, employed since 1998)

Therein, the EPM driven labour process in banks has normalised instrumental and competitive social relationships through the implementation of individualized BSCs and the competitive force of the pre-determined distribution curve that goes in tandem with rewards and disciplinary practices. Though some recently employed bank workers express dissatisfaction with the regime, there is a marked difference in the way bank workers who were employed before the heightening of the market driven EPM regime and those who were recruited under it comply with and adapt to the instrumental rules of engagement that the EPM system promotes.

\section{Disconnect, Dependency, Vulnerability and Re-Connection}

Bank workers who were employed prior to the introduction of the EPM regime display care towards co-workers that is shaped by their attachment to memories of employment that was characterised by a long-term horizon, absent of explicit performance targets and electronic performance monitoring, with high levels of job discretion and varying forms of team work. These conditions are remembered as enabling the sharing of experiences at work, nurturing the formation of trust and, ultimately, respect and recognition between co-workers. A crucial word 
that describes the centrality and value of caring dispositions in the pre-EPM workplace is encoded in interviewees' usage of the metaphor 'family'. Even though families 'are places of disharmony as much as harmony' (Fineman and Gabriel, 2003: 135), the use of this notion captures the web of relationships, which over time gradually fostered caring co-worker relationships that went beyond contractual duties of co-operation and support (Held, 2006).

"We were like a family. We worked for 20-30 years together and there was almost no turnover. We knew a lot about each other, we would go somewhere after work and so on. We helped each other out at work, there was that strong sense of community. We were not just a team, but a collective that cared about each other" (Ruth, clerk, Bank C, employed since 1979)

Co-worker relationships under the pre-EPM workplace regime are characterised by an attentiveness to the vulnerability of others and a relaxed acceptance of a mutual dependency. This is inherent in the following testimonials which indicate social and ethical commitments between staff, expressed by the mutual reciprocity of compassion, benevolence and fellowfeeling that renders the other as an object of value, possessing interdependent interests (Kittay, 1999; Sayer, 2007).

"We were a good bunch of people who looked out after each other. For example, if someone couldn't work $100 \%$, because they didn't feel well or something happened to their granny, others would go the extra mile without complaining or expecting rewards". (Leanne, Teller, Bank A, employed since 1984)

Co-worker relationships are also placed under pressure by the high levels of turn-over and redundancies that targeted primarily experienced bank workers in the mid-1990s. Bank workers who were embedded in the pre-EPM regime experienced the implementation of the EPM system as a violation of the unwritten texture of an ethics of care (Fineman, 2004). This 
is inherent in the expression of moral outrage vis- à -vis a workplace regime that renders people vulnerable to performance pressures and depersonalized electronic performance monitoring, implementing a conditionality within the workplace community that constrains the formulation of human bonds (Held, 2006).

"When all these performance measurements came into full-force and people were made redundant, relationships became less personal. It was a significant change and many of the experienced members said, 'hold on, what is happening here, that isn't right'. But the whole banking industry changed with such a force and fast pace that we felt that things were just happening to us." (Jeff, Customer Consultant, Bank A, employed since 1981).

The context of caring relationships under the pre-EPM system continues to be influential for bank workers; as multi-layered relationships of care are eroded, foundational caring dispositions are maintained. Contradictory relationships of care suggest that experienced bank workers relate to co-workers who were recruited after the implementation of the EPM system through a complex mix of differentiation and compassion. Differentiation is a passive element that evaluates the less experienced group as lacking banking expertise and a wider understanding of the occupation and its social and ethical texture. Yet, inherent in such an understanding is regret concerning the negative transformation of employment conditions and the undermining of rich caring relationships.

“These people are new to the banking industry. They lack the expertise and don't know what they should be doing or what is morally right. For them it is about hitting the targets, get the money and go home" (Scott, Mortgage Advisor, Bank B, employed since 1987).

Nevertheless, experienced bank workers remain embedded in an ethics of care that enables them to express concerns about managerial practices that destroy dependency networks 
(Fineman, 2004; Held, 2006). For example, Elizabeth displays care for those who do not meet targets and have to deal with constant pressure that affects them negatively:

"You have young girls here, 17 years old and you have 50 year old people, and they are all struggling. There are only a few who are good at selling. You feel for these people every day, because I know that it must be horrible to be under that pressure. These people need to bring money home, they work for a reason and every day is such a struggle for them“. (Elizabeth, Customer Advisor, Bank B, employed since 1988)

People's continual attention to others' well-being plays a crucial role for the persistence of care for others, embodying an awareness of an inherent vulnerability and dependency (Fineman, 2004). Despite the undermining of caring relationships, pre-EPM bank workers' ethics of care goes beyond the assessment of current practices as unfair. Indeed, narratives indicate that bank workers search for ways to buffer the instrumentalisation of relationships at work by creating 'affective equality' (Lynch, 2009) so that all can be involved in a cohesive workplace community.

"I always search for light, and if you search hard enough you find it and it is worth fighting for small improvements (...). For example, last month I challenged how two members of staff got labelled as underperformers even though they hit their targets and I went to the manager. These statistical distribution exercises should not happen, they are inhuman and I will continue to challenge them whenever I can”. (Susan, Senior customer advisor, Bank A and C, employed since 1972)

Pre-EPM employees display that evaluative judgments of practices and structures and the recognising of vulnerabilities are at the heart of their relationships to co-workers (Sayer, 2007). Care for others is embedded in the expression of ethical considerations of how to 
improve the situation for co-workers by spending time off work to write an informal guide that aimed to increase co-workers' ability to meet targets:

"It's tough to see the pressure people are under. I see people crying, some are very depressed. I don't think it's fair, I don't think this is how it should be. I wrote something that people started to call "Lisa's Bible", and I handed it out to teams that weren't performing well and those teams who used it increased their sales by $50 \%$. (Lisa, Customer Advisor, Bank D, employed since 1988).

Nevertheless the EPM system rest on an ideology of economic self-sufficiency and separateness from others. This creates 'derivative dependency' (Fineman, 2004) as co-workers, such as Susan and Linda, carry out 'dependency work' to pick up the pieces of a failed employment relationship but are themselves dependent on resources and support mechanisms to help them do so, which are lacking under the new regime (Kittay, 1999).

\section{Co-worker relationships and an ethics of caring under the marketization of bank work}

The ethics of care framework presented in this article views employment as a relationship rooted in a web of social dependencies which, in turn, informs employees' inclination to act in support of others. Such an approach heightens the importance of context and experience that enables or constrains the development of caring dispositions and actions, but also people's capacity to reflect and evaluate what matters to themselves and others. Evidence from the retail banking industry in the UK reveals the importance of people's experiences and embeddedness in environments that enable them to build relationships with co-workers. Our analysis suggests that before the implementation of EPM the working community was characterised by stability and shared interests (Halford and Savage, 1995). There was an understanding of others as vulnerable and dependent beings which fostered 
attentiveness to others' needs. In the context of a highly competitive marketized employment relationship, however, branch work became driven by an EPM system that, through its relentless data gathering and intensification of work processes forms a regimented system that relies on single-minded pursuit of targets which impoverishes existing co-worker relationships and offers no space for new connections to be created and sustained. .

Nevertheless, for long-serving bank workers, the caring co-worker relationships they experienced previously inform an evaluation of the EPM driven regime as a violation of what they deem as right and just. Here, a shared past plays a crucial role in how people mediate, negotiate, filter and experience the demands and pressures the depersonalized and individualising system promotes. In contrast, more recently employed bank workers have a much weaker attachment to a sense of professionalism and community and tend to comply with little reflection on their moral worth. This article illustrates how EPM in banks is experienced by the interviewees as an individualising process that has normalised disconnection. The very vulnerability and dependency upon which an ethic of care is built are not captured, nor tolerated, by the EPM system; indeed it would render bank workers materially vulnerable if they were to depend on others rather than pursue individualised targets. An added hurdle is the dictate around 'ways of being' that boxes people as individual atoms so that it is difficult to establish human connection (Nodding, 2011; Zelizer, 2010).

At the heart of the ethic of care debate, which interviews with bank workers illuminate, is theoretical critique that focuses on the way human development has become conceptually limited by the political rhetoric of the individual subject, inherent in marketized employment practices in general and EPM in particular. People are all too often treated as individual atoms; disembedded from norms, values and community (Kittay, 2011). Such an impoverished picture of humanity is far removed from the reality of lives and workplaces. A 'freedom' to choose, which is a notable characteristic of performance management practices, ignores that choice 
takes place within historical, cultural, political and economic influences that may open or limit and close options (Fineman, 2004: 41/226). Dependency is therefore an important concern, as the imposition of targets and electronic surveillance systems creates fear and competition and undermines the social ontology of dependency; thus attacking a basic cornerstone of humanity. Nevertheless, we suggest that the various forms of care inherent in co-worker relations remain an important aspect of social relations at work under marketization and EPM. Sadly, wtithout the material support they once experienced, bank workers' efforts to introduce caring coworker relationships, which were once the norm, may be met with simple acquiescence, or even disdain, but not necessarily mutuality by the new generation of bank workers who are tuned into the individualised performance management regime.

Applying ethics of care to the analysis of marketized employment enables a fresh interpretation of the multi-layered individual and collective outcomes observed in research on social relations under technologized performance management driven workplaces. It adds an important layer to sociological research on co-worker relationships under marketization by focussing on employees' different experiences of the workplace that may lead to the rise of instrumentalisation, but may also entail practices that aim to 'maintain, continue, and repair relations' (Tronto, 1993: 103). Thus, horizontal and vertical relationships of care become a continual feed into workplace communities that is not a means to achieve greater performance, though this may be an unintended consequence, but an end in itself. In this way, a nuanced approach is offered to explore the impact of electronic performance management on people, their social relations and, ultimately, society.

\section{References}

Ackroyd, S. and P Thompson (1999), Organizational Misbehaviour (London: Sage). 
Armstrong, M. (2009) 'The Process of Performance Management', in M. Armstrong, A Handbook of Human Resource Management Practice, pp.617-638 (London: Kogan Page Limited).

Benhabib, S. (1992), Situating the Self (Cambridge: Polity).

Bach, S. (ed.) (2005), 'New Directions in Performance Management', in S. Bach (ed.), Managing Human Resources, pp.289-316 (Malden: Blackwell Publishing).

Booth, A. (2004), 'Technical change in branch banking at the Midland Bank 1945-75', Accounting, Business \& Financial History, 14(3), 277-300.

Boreham, P., R. Parker, P. Thompson and R. Hall (2008), New Technology@ Work (London and New York: Routledge).

Burawoy, M. (1979), Manufacturing consent (Chicago: University of Chicago Press).

Carter, B., Danford, A, D. Howcroft, et al. (2011) 'All they lack is a chain': Lean and the new performance management in the British civil service, New Technology, Work and Employment, 26(2), 83-97.

Casey, C. (1995), Work, Self and Society after Industrialism (London: Routledge).

Crompton, R. and G. Jones (1984), White Collar Proletariat: Deskilling and Gender in Clerical Work (London: Macmillan).

Cushen, J. and P. Thompson (2016), 'Financialization and value: why labour and the labour process still matter', Work, employment and society (in press).

Deloitte (2007), Winning with branches. London: Deloitte LLP.

Donati, P. and M.S. Archer (2015), The Relational Subject (Cambridge: Cambridge University Press).

Edwards, P. and P. Ramirez (2016), 'When should workers embrace or resist new technology?', New Technology, Work and Employment, 31, 99-113.

Ellis, V. and P. Taylor (2006), 'You Don't KnowWhat You've Got till It's Gone: ReContextualising the Origins, Development and Impact of the Call Centre', New Technology, Work and Employment, 21, 107-122.

Ellis, V. and M. Taylor (2010), 'Banks, bailouts and bonuses: a personal account of working in Halifax Bank of Scotland during the financial crisis', Work, Employment and Society, 24, 803-12.

Fevre, R. (2003), The new sociology of economic behaviour (London: Sage).

Fevre, R., Lewis, D., Robinson, A. and T. Jones (2012), Trouble at Work (London: Bloomsburry Publishing).

Fineman, M. (2004), The Autonomy Myth (New York: New Press). 
Fineman, S. and Y. Gabriel (2003), Experiencing Organizations (London: SAGE).

Froud, J., Tischer, D and K. Williams (2017) 'It is the business model... Reframing the problems of UK retail banking', Critical Perspectives on Accounting, 42, pp. 1-19. Online first.

Gabriel, Y. (2008), 'Latte capitalism and late capitalism: Reflections on fantasy and care as part of the service triangle', in: Korczynski, M. and C. MacDonald (eds): Service work: Critical perspectives, pp. 175-190 (London: Routledge).

Gall, G. (2008), Labour Unionism in the Financial Services Sector: Fighting for Rights and Representation (London: Ashgate Publishing).

Gilligan, C. (1982), In A Different Voice (Cambridge: Harvard University Press).

Grosen, S. (2014), 'Working with standards: the post-crisis positioning of bank workers', New Technology, Work and Employment, 29, 253-265.

Halford S and M Savage (1995), Restructuring organizations, changing people: gender and restructuring in banking and local government, Work, Employment and Society, 9(1): 97-122.

Hall, D. (1984), America's working man (Chicago: University of Chicago Press).

Hassard, J., McCann, L. and J Morris (2009), Managing in the Modern Corporation (Cambridge: Cambridge University Press).

Held, V. (2006), The Ethics of Care: Personal, Political, and Global (Oxford: Oxford University Press).

Hodgson, D. (2003), "Taking it Like a Man': Masculinity, Subjection and Resistance in the Selling of Life Assurance', Gender, Work and Organization, 10:1, 1-21.

Hodson, R (2001), Dignity at Work (Cambridge: Cambridge University Press).

Hodson, R. (2008), 'The Ethnographic Contribution to Understanding Coworker Relations', British Journal of Industrial Relations, 46, 169-192.

Honnegger, C, Neckel, S and M Chantal (2010), Strukturierte Verantwortungslosigkeit Berichte aus der Bankenwelt, (Frankfurt:Suhrkamp Verlag).

Jeske, S. and A Santuzzi (2015), 'Monitoring what and how: psychological implications of electronic performance monitoring', New Technology, Work and Employment, 30, 62-78

Kittay, E. F. (1999), Love's Labor: Essays on Women, Equality, and Dependency (New York: Routledge).

Kittay, E. F. and E. K. Feder (2003), The Subject of Care: Feminist Perspectives on Dependency (Lanham, MD: Rowman \& Littlefield). 
Knights, D (1997), An Industry in Transition: Regulation, Restructuring and Renewal, in Knights, D. and T. Tinker, Financial Institutions and Social Transformations: International Studies of a Sector (London: MacMillan Press), 1-27.

Knights, D. and D. McCabe (2001), 'A Different World': Shifting Masculinities in the Transition to Call Centres', Organization 8(4), 619-645.

Korczynski, M. (2003), 'Communities of Coping: Collective Emotional Labour in Service Work', Organization 10, 55-79.

Korczynski, M. and U. Ott (2005), 'Sales work under marketization', Organization Studies 26, 707-28.

Lopez, S. (2010), 'Workers, Managers, and Customers: Triangles of Power in Work Communities', Work and Occupation 37, 251-271.

Lynch, K. (2009), 'Affective Equality: Who Cares?', Development 52, 410-415.

Lyon, D. (2001), Surveillance Society: Monitoring Everyday Life (Philadelphia, PA: Open University Press).

McCabe, D. (2011), 'Accounting for Consent: Exploring the Reproduction of the Labour Process' Sociology 45(3), 430-446.

McCabe, D. (2014), 'Making out and making do: how employees resist and make organisational change work through consent in a UK bank', New Technology, Work and Employment, 29, 57-71.

McCabe, D. (2015), 'Numericalizing the other: a critical analysis of a strategy discourse in a UK bank’. Organization 23, 525-549

McGovern, P., S. Hill, C. Mills and M White (2007), Market, Class and Employment (Oxford: Oxford University Press).

McGuire, M. (2007), 'Intimate Work: A Typology of the Social Support that Workers Provide to Their Network Members'. Work and Occupations 34, 125-47.

Morgan, G. and A. Sturdy (2000) Beyond Organizational Change: Structure, Discourse and Power in UK Financial Services (London: Palgrave Macmillan UK ).

Newsome, K. Thompson, P. and J Commander (2013), 'You monitor performance at every hour': labour and the management of performance in the supermarket supply chain'. New Technology, Work and Employment 28, 1-15.

O'Reilly, J. (1992), Banking on Flexibility: a Comparison of the Use of Flexible Employment Strategies in the Retail Banking Sector in Britain and France', The International Journal of Human Resource Management 3(1): 35-58.

Pearson, C.M., Andersson, L.M. and J.W. Wegner (2001), 'When workers flout convention: A study of workplace incivility', Human Relations 54, 1387-419. 
Rafnsdóttir, G.L. and M.L. Gudmundsdottir (2011), 'EPM Technology and the Psychosocial Work Environment', New Technology, Work and Employment 26, 210-221.

Regini, M. Kitay, J. and M Baethge (eds) (1999), From tellers to sellers (Cambridge, MA: MIT Press).

Sayer, A. (2007), 'Moral economy and employment', in: Bolton SC and Houlihan M (eds) Searching for the Human in Human Resource Management: Theory, Practice and Workplace Contexts, pp.21-40 (London: Palgrave).

Sayer, A. (2011), Why Things Matter to People: Social Science, Values and Ethical Life (Cambridge: Cambridge University Press).

Sennett, R. (2006), The Culture of the New Capitalism (New Haven: Yale University Press).

Sevenhuijsen, S. (1998), Citizenship and the ethics of care: Feminist Considerations on Justice, Morality and Politics (New York: Routledge).

Sloan, M. (2012), 'Unfair Treatment in the Workplace and Worker Well-Being: The Role of Coworker Support in a Service Work Environment', Work and Occupations, 39, 3-34.

Storey, J (1995) 'Employment Policies and Practices In Uk Clearing Banks: an Overview', Human Resource Management Journal 5(4), 24-43.

Robinson F (2011), The Ethics of Care: A Feminist Approach to Human Security. Philadelphia: Temple University Press.

Roscigno, V. J., Hodson, R. Lopez, S. H. (2009), 'Workplace incivilities: the role of interest conflicts, social closure and organizational chaos', Work, Employment \& Society 23, 747-773.

Roy, D. (1954), 'Efficiency and the Fix: Informal Intergroup Relations in a Piecework Machine Shop', American Journal of Sociology 60, 255-66.

Rumens, N. (2010), 'Firm Friends: Exploring the Supportive Components in Gay Men's Workplace Friendships'. The Sociological Review 58, 135-55.

Taylor, P. (2013), Performance Management and the New Workplace Tyranny: A Report for the Scottish Trades Union Congress (Glasgow: University of Strathclyde).

Taylor, P. and S. Moore (2015), 'Cabin crew collectivism: labour process and the roots of mobilisation in the British airways dispute 2009-11', Work, Employment and Society, 29, 7998.

Findlay, P and P. Thompson (2017), Contemporary work: its meanings and demands. Industrial Relations Journal, online first.

Tronto, J. C. (1993), Moral Boundaries (London: Routledge). 
Watson, K. (2004), 'The financial services sector since 1945'. In: Floud RJ (ed.) The Cambridge Economic History of Modern Britain, pp. 167-187 (Cambridge: Cambridge University Press).

Zelizer, V. (2010), 'Caring Everywhere', in: Boris, E. and Salazar, R. P (ed.) Intimate Labors: Cultures, Technologies, and the Politics of Care (Stanford: Stanford University Press). 